\title{
Nursing, Psychiatric, and Home Health Aides
}

National Cancer Institute

\section{Source}

National Cancer Institute. Nursing, Psychiatric, and Home Health Aides. NCI Thesaurus.

Code C122487.

Nursing aides, orderlies, and attendants provide basic patient care under direction of nursing staff; performed duties include feeding, bathing, dressing, grooming, moving patients, and chang ing linens. Psychiatric aides assist mentally impaired or emotionally disturbed patients, working under direction of nursing and medical staff. Home health aides provide routine, personal healthcare, such as bathing, dressing, or grooming, to elderly, convalescent, or disabled persons in the home of patients or in a residential care facility. 